\title{
PENGGUNAAN SIG UNTUK OPTIMASI POLA PENGUMPULAN DAN PENGANGKUTAN SAMPAH DARI TEMPAT PEMBUANGAN SEMENTARA (TPS) KE TEMPAT PEMBUANGAN AKHIR (TPA)
}

\author{
Yuli Pratiwi ${ }^{1}$, Paramita Dwi Sukmawati ${ }^{2}$, Dede Ramdhan Andriana ${ }^{3}$ \\ ${ }^{1,2,3}$ Program Studi Teknik Lingkungan, Fakultas Sains Terapan, Institut Sains \& Teknologi \\ AKPRIND Yogyakarta \\ Alamat email: yuli_pratiwi@akprind.ac.id
}

Masuk: 17 Januari 2021, Revisi masuk: 23 Februari 2021, Diterima: 3 Agustus 2021

\begin{abstract}
Garbage transportation aims to carry waste from the transfer location or from the waste source directly to the Final Disposal Site (TPA).. This study aims to 1)know the distribution of Temporary Disposal Sites (TPS) in 5 sub districts located in Karawang Regency,. 2) know the existing route of garbage transportation in Karawang Regency with the help of Geographic Information System (SIG), 3) analyze and evaluate the effectiveness and efficiency of existing waste transportation routes in Karawang Regency and 4) calculate the level of needs of waste transportation vehicles needed in Karawang Regency.

The research was conducted in West Karawang District, East Karawang, West Telukjambe, East Telukjambe and Klari in Karawang Regency in January - February 2020. To optimize the pattern of garbage collection and transportation using Geographic Information System (GIS) with network analyst method. This method determines the optimal route so that it can be effective and efficient in the waste transport system. The data used are poll location, TPS and TPA, number of TPS, time and distance traveled, existing transportation route, distance between pool and TPS-TPS and distance between TPS-TPA, number of vehicles.

The results of the study on 5 sub districts in Karawang district of garbage transportation vehicles that operate as many as 38 units and 111 TPS. The existing garbage transport line, the average distance is $91.08 \mathrm{~km}$ and the travel time is 3.63 hours while the garbage transportation line that has been analyzed obtained an average distance of $43.94 \mathrm{~km}$ and a travel time of 2.32 hours. So it has a distance difference of $53.94 \mathrm{~km}$ and a travel time of 1.31 hours on 38 garbage transportation. Estimated waste generated 1,532,234 m3/day Currently the number of vehicles in the pool is as many as 38 units. The cost of vehicle fuel consumption on existing routes amounted to Rp. 4,133,735 per day after analysis to Rp. 2,633,879 per day, so the decrease of $R p .1,479,856$ per day means it can save operational costs of garbage transportation.
\end{abstract}

Keywords: GIS, network analyst, optimization, transportation routes, waste,

\section{INTISARI}

Transportasi sampah bertujuan membawa sampah dari lokasi pemindahan atau dari sumber sampah secara langsung menuju Tempat Pembuangan Akhir (TPA). Penelitian ini bertujuan untuk 1)mengetahui sebaran Tempat Pembuangan Sementara (TPS) pada 5 Kecamatan yang terdapat di Kabupaten Karawang, 2)mengetahui jalur eksisting pengangkutan sampah di Kabupaten Karawang dengan bantuan Sistem Informasi Geografis (SIG), 3)menganalisis dan mengevaluasi efektivitas dan efisiensi rute pengangkutan sampah yang ada saat ini di Kabupaten Karawang dan 4)menghitung tingkat kebutuhan kendaraan pengangkutan sampah yang dibutuhkan di Kabupaten Karawang.

Penelitian dilaksanakan di Kecamatan Karawang Barat, Karawang Timur, Telukjambe Barat, Telukjambe Timur dan Klari di Kabupaten Karawang pada bulan Januari - Februari 2020. Untuk melakukan optimasi pola pengumpulan dan pengangkutan sampah menggunakan Sistem Informasi Geografis (SIG) dengan metode Network Analyst. Metode ini menentukan rute yang optimal sehingga dapat efektif dan efisien dalam sistem pengangkutan sampah. Data yang digunakan adalah lokasi poll, TPS dan TPA, jumlah TPS, waktu dan jarak perjalanan yang ditempuh, rute angkutan eksisting, jarak antara pool dengan TPS-TPS dan jarak antara 
TPS-TPA, jumlah kendaraan. Garbage transportation vehicles needed as many as 128 units which means that additional vehicles need as many as 90 units.

Hasil penelitian pada 5 Kecamatan di Kabupaten Karawang kendaraan pengangkutan sampah yang beroperasi sebanyak 38 unit dan 111 TPS. Jalur eksisting pengangkutan sampah, rata-rata jaraknya $91,08 \mathrm{~km}$ dan waktu tempuh 3,63 jam sedangkan jalur pengangkutan sampah yang sudah dianalisis didapatkan jarak rata-rata 43,94 km dan waktu tempuh 2,32 jam. Jadi mempunyai selisih jarak 53,94 km dan waktu tempuh 1,31 jam pada 38 pengangkutan sampah. Estimasi timbulan sampah yang dihasilkan $1.532,234 \mathrm{~m}^{3}$ /hari. Pada saat ini jumlah kendaraan yang terdapat di pool sebanyak 38 unit. Kendaraan pengangkutan sampah yang dibutuhkan sebanyak 128 unit yang artinya perlu tambahan kendaraan sebanyak 90 unit. Biaya konsumsi bahan bakar kendaraan pada rute eksisting sebesar Rp. 4.133 .735 per hari sedangkan sesudah dilakukan analisis menjadi Rp. 2.633 .879 per hari, jadi penurunan sebanyak Rp. 1.479 .856 per hari berarti bisa menghemat biaya operasional pengangkutan sampah.

Kata-kata kunci: network analysis, optimasi, rute pengangkutan, sampah, SIG

\section{PENDAHULUAN}

Kabupaten Karawang merupakan salah satu kota yang mengalami permasalahan di bidang pengelolaan persampahan, khususnya pada sistem pengangkutan sampah. Pada 5 Kecamatan yang terdapat di Kabupaten Karawang yaitu Kecamatan Karawang Barat, Karawang Timur, Telukjambe Barat, Telukjambe Timur dan Klari memiliki luas wilayah $270,19 \mathrm{~km}^{2}$ dengan jumlah penduduk 557,176 jiwa (Badan Pusat Statistik 2019). Pada 5 Kecamatan ini merupakan sentral industri yang mengalami perkembangan semakin pesat sehingga akan menyebabkan kenaikan jumlah penduduk. Dengan pertambahan jumlah penduduk akan mengakibatkan timbulan sampah semakin meningkat.

Dengan menggunakan metode Sistem Informasi Geografis (SIG) diharapkan dapat mencari jalur optimum atau jalur tercepat kendaraan dalam pengangkutan sampah dengan parameter jarak dan waktu tempuh pengangkutan serta dapat menentukan rute pembagian kendaraan pengangkut sampah yang efektif dan efisien sehingga dapat mengurangi dan meminimalkan timbulan sampah yang terdapat di Tempat Pembuangan Sementara (TPS).

Berdasarkan latar belakang permasalahan yang telah dipaparkan, maka permasalahan yang dapat dirumuskan yaitu, Berapa jumlah Tempat Pembuangan
Sementara (TPS) yang terdapat pada 5 Kecamatan di Kabupaten Karawang?,

Bagaimana proses pengangkutan sampah pada wilayah pelayanan di Kabupaten Karawang?, Bagaimana jalur eksisting yang diterapkan dalam pengangkutan sampah yang terdapat pada setiap wilayah pelayanan yang ada di Kabupaten Karawang?, dan Berapa tingkat kebutuhan kendaraan pengangkutan sampah yang dibutuhkan pada 5 Kecamatan di Kabupaten Karawang?.

Penelitian ini bertujuan untuk mengetahui sebaran Tempat

Pembuangan Sementara (TPS) pada 5 Kecamatan yang terdapat di Kabupaten Karawang, mengetahui jalur eksisting pengangkutan sampah di Kabupaten Karawang dengan bantuan Sistem Informasi Geografis (SIG), menganalisis dan mengevaluasi efektivitas dan efisiensi rute pengangkutan sampah yang terdapat pada 5 Kecamatan di Kabupaten Karawang dan menghitung tingkat kebutuhan kendaraan pengangkutan sampah yang dibutuhkan pada 5 Kecamatan di Kabupaten Karawang.

Menurut Sejati (2009), Sampah adalah suatu bahan yang terbuang atau dibuang dan merupakan hasil aktivitas manusia maupun alam yang sudah tidak dapat digunakan lagi karena sudah diambil unsur atau fungsi utamanya.

Estimasi timbulan sampah merupakan dasar dari perencanaan, perancangan, dan pengkajian sistem pengelolaan sampah. Berikut adalah perhitungan estimasi timbulan sampah. Menurut SNI 19-3983-1995, bila pengamatan lapangan belum tersedia, maka untuk menghitung 
besaran sistem dapat digunakan angka timbulan sampah sebagai berikut:

Estimasi Timbulan Sampah

$\mathrm{Vs}=\mathrm{Po} \times \mathrm{v}$

Keterangan:

Po: Jumlah penduduk

$\mathrm{V}$ : Rata - rata volume sampah yang dihasilkan

Tabel 1. Timbulan sampah berdasarkan klasifikasi kota

\begin{tabular}{|c|c|c|c|}
\hline No & Klasifikasi Kota & $\begin{array}{c}\text { Volume } \\
\text { (L/Orang/ } \\
\text { Hari) }\end{array}$ & $\begin{array}{c}\text { Berat } \\
\text { (Kg/Orang } \\
\text { Hari) }\end{array}$ \\
\hline 1 & $\begin{array}{c}\text { Kotabesar(500.000- } \\
1.000 .000 \text { jiwa) }\end{array}$ & $2,75-3,25$ & $0,70-0,80$ \\
\hline 2 & $\begin{array}{c}\text { Kota sedang } \\
\text { (100.000- } \\
500.000 \text { iiwa) }\end{array}$ & $2,75-3,25$ & $0,70-0,80$ \\
\hline 3 & $\begin{array}{c}\text { Kota kecil } \\
(20.000-100.000 \\
\text { iiwa) }\end{array}$ & $2,50-2,75$ & $0,625-0,70$ \\
\hline
\end{tabular}

(Sumber: SNI 19-3983-1995)

Menurut Arinal Haq dkk (2013), Pengangkutan sampah adalah sub- sistem yang bertujuan membawa sampah dari Tempat Pembuangan Sementara (TPS) atau dari sumber sampah secara langsung menuju Tempat Pembuangan Akhir (TPA). Tujuan pengangkutan sampah adalah menjauhkan sampah dari perkotaan ke TPA yang terdapat jauh dari kawasan perkotaan dan pemukiman.

Menurut Angreliany (2014), Perencanaan dan perhitungan jumlah kebutuhan trip/hari kendaraan pengangkutan sampah menggunakan sistem SCS digunakan persamaan berikut :

1. Menghitung jumlah trip kendaraan per hari dengan pola sistem SCS adalah sebagai berikut:

TSCS $=$ PSCS $+x+S$

$$
\mathrm{Nd}=\{\mathrm{H}(1-\mathrm{W})-(\mathrm{t} 2+\mathrm{t} 1)\} / T S C S
$$

Keterangan:

$\mathrm{Nd}$ : Jumlah trip/hari

$\mathrm{H}$ : Waktu kerja per hari $=6$ jam

t1 : Waktu pool ke lokasi TPS pertama

t2 : Waktu kendaraan pengangkut dari TPA/ lokasi terakhir kembali ke pool

$x$ : Waktu tempuh rata-rata TPS- TPA

$S$ : Waktu rata-rata pembongkaran di TPA

$\mathrm{W}$ : off route factor

Menurut Angreliany (2014),

Perhitungan waktu off rute pengangkutan sampah dapat dilihat pada Tabel 2.

Tabel 2. Perhitungan waktu off route (W)

\begin{tabular}{|c|c|c|c|}
\hline No & Uraian Kegiatan & Menit & jam \\
\hline 1 & $\begin{array}{l}\text { Persiapan, checking } \\
\text { rutin kendaraan }\end{array}$ & 12 & 0,2 \\
\hline 2 & Sarapan pagi & 12 & 0,2 \\
\hline 3 & $\begin{array}{l}\text { Pencucian bak } \\
\text { sebelum kembali } \\
\text { lagi ke pool }\end{array}$ & 11 & 0,18 \\
\hline 4 & Pengisian BBM & 6 & 0,1 \\
\hline 5 & Ganti ban bocor & 15 & 0,25 \\
\hline & Jumlah & & 0,93 \\
\hline & Rasio & & $0,93 / 6=0,15$ \\
\hline
\end{tabular}

2. Menghitung jumlah trip kendaraan per hari dengan pola sistem kontainer angkat HCS digunakan persamaan- persamaan sebagai berikut:

$\mathrm{P}$ hcs $=\mathrm{pc}+\mathrm{uc}+$

$\mathrm{dbc} \mathrm{T}$ hcs $=\mathrm{P}$

$h c s+h+S$

$\mathrm{Nd}=\{\mathrm{H}(1-\mathrm{W})-(\mathrm{t} 2+\mathrm{t} 1)\} /$ Thcs

Keterangan:

$\mathrm{H}$ : Waktu dari TPS ke TPA ke kontainer berikutnya

$\mathrm{t} 1$ : Waktu tempuh dari pool ke kontainer

t2 : Waktu dari TPS ke lokasi terakhir kembali ke pool

pc: Waktu mengambil kontainer (jam/menit)

uc: Waktu meletakkan kontainer (jam/menit)

dbc:Waktu antar kontainer (jam/menit)

S: Waktu menunggu dan membongkar di TPA (jam)

Menurut Pramartha, (2013), perhitungan jumlah truk yang dibutuhkan untuk sistem SCS dan HCS yaitut:

1. menentukan jumlah trip/hari: Jumlah trip/hari = Timbulan sampah yang dihasilkan $\left(\mathrm{m}^{3}\right) /$ hari/kapasitas truk $\left(\mathrm{m}^{3}\right)$.

2. Kebutuhan truk untuk melakukan trip/hari 
Menurut Susanta Nugraha (2013), Sistem Informasi Geografis (SIG) atau Geographic Information System (GIS) adalah sebuah sistem yang didesain untuk menangkap, menyimpan, memanipulasi, menganalisa, mengatur dan menampilkan seluruh jenis data geografis.

Network Analyst (NA) secara umum adalah pemodelan transportasi untuk melihat hubungan antar objek yang dihubungkan oleh jaringan transportasi. Network analyst menyediakan analisis spasial berbasis jaringan, seperti routing, rute armada, arah perjalanan, fasilitas terdekat, area layanan, dan dari satu lokasi ke lokasi lainnya (Ristandi, 2004).

Menurut Ofyar (2000), Proses pemilihan rute bertujuan untuk memodelkan pergerakan dalam memilih rute yang terbaik. Dengan mengasumsikan bahwa setiap pengendara memilih rute yang meminimumkan biaya perjalanan (bisa juga meminimumkan jarak dan waktu tempuh), maka adanya penggunaan ruas yang lain disebabkan persepsi biaya untuk menghindari kemacetan.

\section{METODE PENELITIAN}

Penelitian ini dilakukan menggunakan pendekatan kuantitatif dengan cara mengikuti kendaraan pengangkutan sampah mulai dari pool kendaraan menuju ke masing-masing lokasi tiap TPS hingga menuju ke TPA dan dilakukan identifikasi lokasi dengan alat Avenza Maps.

Penelitian ini dilaksanakan di Kecamatan Karawang Barat, Karawang Timur, Telukjambe Barat, Telukjambe Timur dan Klari di Kabupaten Karawang pada bulan Januari - Februari 2020.

Pengumpulan data primer antara lain: 1) lokasi pool, TPS dan TPA, 2)waktu perjalanan yang ditempuh, 3) jarak lokasi yang ditempuh, 4) jumlah TPS, 5)kapasitas atau tipe TPS, 6) jumlah kendaraan dan kapasitas angkut kendaraan, 7) waktu operasional pengangkutan sampah, 8) pengumpulan data dengan metode wawancara pihak terkait dalam kegiatan pengelolaan sampah seperti staff, pengawas, supir, dan pekerja dengan proses tanya-jawab dalam penelitian yang berlangsung secara lisan untuk mendapatkan informasi atau keterangan yang berkaitan dengan pola pengumpulan dan pengangkutan sampah.
Adapun data sekunder yang digunakan pengumpulan melalui dokumen dan catatan terkait untuk memenuhi kebutuhan dalam penelitian pada Tabel 3 .

Tabel 3. Data penelitian dan sumber data

\begin{tabular}{|c|c|c|}
\hline \multicolumn{3}{|c|}{ yang digunakan } \\
\hline No & Data & Sumber Data \\
\hline 1 & Jumlah penduduk & \begin{tabular}{|l} 
Badan Statısttık \\
Kabupaten Karawang
\end{tabular} \\
\hline 2 & $\begin{array}{l}\text { Data timbulan sampah } \\
\text { yang terdapat di } \\
\text { Kabupaten Karawang }\end{array}$ & \multirow{4}{*}{$\begin{array}{l}\text { Dinas Lingkungan } \\
\text { Hidup dan } \\
\text { Kebersihan } \\
\text { Kabupaten Karawang }\end{array}$} \\
\hline 3 & $\begin{array}{l}\text { Data jumlah kendaraan } \\
\text { dan jenis pengangkut } \\
\text { sampah }\end{array}$ & \\
\hline 4 & $\begin{array}{l}\text { Data lokasi pool truk, } \\
\text { TPS dan TPA }\end{array}$ & \\
\hline 5 & $\begin{array}{l}\text { Jumlah personil dan } \\
\text { pengendalian pelaksanaan } \\
\text { (pengawasan) }\end{array}$ & \\
\hline 6 & Peta batas administrasi & \multirow{2}{*}{$\begin{array}{l}\text { Dinas Pekerjaan } \\
\text { Umum/Bappeda } \\
\text { Kabupaten Karawang }\end{array}$} \\
\hline 7 & Peta jaringan jalan & \\
\hline
\end{tabular}

Data input yang diperlukan untuk mengoptimasi rute pengangkutan berupa length (panjang jalan) adalah peta jaringan jalan dan batas administrasi, Input selanjutnya menentukan titik koordinat atau stop yaitu seperti pool kendaraan, TPS-TPS yang dilayani dan TPA, Stop 1 berarti pool kendaraan dimana truk mulai berangkat dan stop terakhir TPA. Kemudian dilakukan running ekstensi pada Network Analyst untuk menentukan jalur pengangkutan sampah.

\section{PEMBAHASAN}

Luas wilayah Kabupaten Karawang sebesar $1.753,27 \mathrm{~km}^{2}$ atau 3,73\% dari luas Provinsi Jawa Barat. Kabupaten Karawang merupakan salah satu daerah yang memiliki lahan subur di Jawa Barat, sehingga sebagian besar lahannya digunakan untuk pertanian. Kabupaten Karawang secara administratif terdiri dari 30 kecamatan, 297 desa dan 12 kelurahan. Berdasarkan data pada 5 kecamatan dalam angka 2018 di Kabupaten Karawang memiliki jumlah penduduk sebanyak 557.176 jiwa dan kepadatan penduduk sebesar $757.393 \mathrm{~km}^{2}$. Banyaknya jumlah penduduk pada tahun 2018 yaitu luas wilayah, penduduk dan kepadatan penduduk pada 5 Kecamatan pada tahun 2018 masing-masing tercantum pada Tabel 4. 
Tabel 4. Luas wilayah, jumlah penduduk, dan kepadatan penduduk menurut 5 Kecamatan pada tahun 2018

\begin{tabular}{|c|l|c|c|c|}
\hline No & Kecamatan & $\begin{array}{c}\text { Luas } \\
\text { Wilayah } \\
\left(\mathrm{km}^{2}\right)\end{array}$ & $\begin{array}{c}\text { Jumlah } \\
\text { Penduduk } \\
\left(\mathrm{km}^{2}\right)\end{array}$ & $\begin{array}{c}\text { Kepadatan } \\
\text { Penduduk } \\
\text { per km }\end{array}$ \\
\hline 1 & $\begin{array}{c}\text { Karawang } \\
\text { Barat }\end{array}$ & 33.68 & 140,171 & 4,162 \\
\hline 2 & $\begin{array}{l}\text { Karawang } \\
\text { Timur }\end{array}$ & 73.65 & 108.589 & 1,474 \\
\hline 3 & $\begin{array}{l}\text { Telukjambe } \\
\text { Barat }\end{array}$ & 73.36 & 54.549 & 744 \\
\hline 4 & Telukjambe & 40.13 & 112.023 & 2,792 \\
\hline 5 & Timur & 49.37 & 141.844 & 2,873 \\
\hline
\end{tabular}

(Sumber: Badan Pusat Statistik Kabupaten Karawang, 2019)

Pengangkutan sampah tersebut dilakukan setiap hari oleh Dinas Cipta Karya dan Dinas Lingkungan Hidup dan Kebersihan Kabupaten Karawang. Armada pengangkutan sampah dioperasikan setiap pagi hari mulai pukul 05.00 WIB. Pada pengangkutan sampah yang diterapkan di wilayah Kabupaten Karawang yang terdiri dari seratus sebelas (111) TPS yang tersebar di 5 kecamatan. Setiap kendaraan pengangkutan sampah terdapat 1 supir kendaraan dan 3 petugas pengangkutan sampah yang mengangkut sampah setiap hari. Pada pengangkutan sampah menuju ke TPA dilakukan pergantian supir kendaraan dan keberangkatan kendaraan dilakukan pada jam 01.00 WIB.

Berdasarkan jumlah penduduk pada 5 kecamatan di Kabupaten Karawang pada tahun 2018 adalah sebesar 557,176 jiwa (Sumber:Badan Pusat Statistik 2019). Menurut SNI 19-3983-1995 bila pengamatan lapangan belum tersedia, maka untuk menghitung besaran sistem dapat digunakan angka timbulan sampah sebagai berikut:

Estimasi Timbulan Sampah:

$\mathrm{Vs}=\mathrm{Po} \times \mathrm{V}$

Keterangan:

Po: jumlah penduduk pada 5 Kecamatan di Kabupaten Karawang

$\mathrm{v}$ : rata - rata volume sampah yang dihasilkan

Berdasarkan SNI 19-3983-1995 diatas 5 kecamatan di Kabupaten Karawang termasuk dalam kategori kota sedang/besar yaitu 2,75 L/Orang/Hari. Maka volume sampah yang dihasilkan:

$\mathrm{Vs}=\mathrm{Po} \times \mathrm{v}$

$=557.176$ jiwa $\times 2,75$ L/Orang/Hari/1000

$=1.532,234 \mathrm{~m}^{3} /$ hari
Sarana pengangkutan yang dimiliki oleh Dinas Lingkungan Hidup dan Kebersihan Kabupaten Karawang pada 5 Kecamatan dapat dilihat pada Tabel 5.

Tabel 5. Jumlah sarana pengangkutan sampah pada 5 kecamatan

\begin{tabular}{|l|c|c|c|c|}
\hline $\begin{array}{c}\text { Alat } \\
\text { Pengangkutan } \\
\text { Sampah }\end{array}$ & Jumlah & Unit & $\begin{array}{c}\text { Kapasitas } \\
\left(\mathrm{m}^{3}\right)\end{array}$ & \multicolumn{2}{|c|}{ Kondisi (unit) } \\
\cline { 4 - 5 } & & & Baik & Rusak \\
\hline Dump truck & 21 & 6 & 21 & 0 \\
\hline Arm rool truck & 14 & 6 & 14 & 0 \\
\hline Compactor & 3 & 6 & 3 & 0 \\
\hline Jumlah & 38 & & 38 & \\
\hline
\end{tabular}

(Sumber: DLHK,2018)

Sarana Tempat Pembuangan Sementara yang terdapat pada Kecamatan Karawang Barat, Karawang Timur, Telukjambe Barat, Telukjambe Timur, dan Klari dapat dilihat pada Tabel 6.

Tabel 6. Jumlah TPS yang dilayani oleh

Dinas Lingkungan Hidup dan Kebersihan Kabupaten Karawang

\begin{tabular}{|l|c|c|}
\hline Kecamatan & $\begin{array}{c}\text { Jumlah } \\
\text { TPS }\end{array}$ & $\begin{array}{c}\text { Jumlah Petugas } \\
\text { Pengambil Sampah }\end{array}$ \\
\hline Karawang Barat & 37 & 4 \\
\hline Karawang Timur & 35 & 4 \\
\hline Telukjambe Barat & 2 & 4 \\
\hline Telukjambe Timur & 34 & 4 \\
\hline Klari & 3 & 4 \\
\hline
\end{tabular}

(Sumber: DLHK,2018)

Perencanaan rute optimal ini didapatkan dari pendataan jalan yang dilalui pada proses pengangkutan menuju masingmasing TPS dengan tujuan akhir menuju TPA. Proses pencarian TPS terdekat dari pool truck sebagai starting point untuk mendapatkan rute terpendek merupakan langkah pertama untuk melakukan analisis pada titik dan rute pengangkutan sampah. Tabel 7 menunjukkan perbedaan rute eksisting dan rute alternatif yang didapatkan setelah dianalisa dengan Network Analyst. 
Tabel 7. Perbandingan rute eksisting dan rute alternatif

\begin{tabular}{|c|c|c|c|}
\hline & Kendarasn & Rute Eksisting & Rute Allemgiff \\
\hline 1 & \begin{tabular}{|l|} 
Tarmin Mihsrig \\
Dump truck-T8801F
\end{tabular} & $\begin{array}{l}\text { Pool-TPS JI. Kentabumi-TPS JI. Nigga -TPS } \\
\text { Anjun-TPS RS. Bayukarta-Pool-TPA-Pool }\end{array}$ & $\begin{array}{l}\text { Pool-TPS RS. Bayukarts-TPS Jalan Nisga-TPS } \\
\text { Anjun-TPS JI. Kertabumi-TPA.Pool }\end{array}$ \\
\hline 2 & \begin{tabular}{|l|} 
Aj Sermagi \\
Dumptruck-T8137D
\end{tabular} & $\begin{array}{l}\text { Fool.TPS Pasar baru Karawang-Pool-TPA- } \\
\text { Pool }\end{array}$ & Pool-Passar Bru Kargwang-TPA-Pool \\
\hline 3 & $\begin{array}{l}\text { Onem S } \\
\text { Dump truck-T8633F }\end{array}$ & 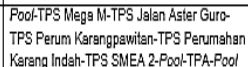 & \begin{tabular}{|l} 
Pool-TPS Perum Karrangpawitan-TPS SMEA 2- \\
TPS Jalan Aster Guro-TPS Mega M-TPA-Pool
\end{tabular} \\
\hline 4 & $\begin{array}{l}\text { Andri } \\
\text { Dump truck-T8808F }\end{array}$ & $\begin{array}{l}\text { Pool-TPS JI. Dewi Sartikg-TPS JI. Niags-RS. } \\
\text { Dewi Sri-Pool-TPA.Pool }\end{array}$ & $\begin{array}{l}\text { Pool-TPS JI. Dewi Sartika-TPS J1. Niag-TPS RS. } \\
\text { Dewi Sri-TPA-Fool }\end{array}$ \\
\hline 5 & $\begin{array}{l}\text { Didi } \\
\text { Dump truck- T8737F }\end{array}$ & $\begin{array}{l}\text { Pool-TPS Paseur Jayg-TPS Bintang Alam- } \\
\text { Pool-TPA-Pool }\end{array}$ & $\begin{array}{l}\text { Pool-TPS Paseur Jays-TPS Bintang Alam-TPA- } \\
\text { Pool }\end{array}$ \\
\hline 8 & \begin{tabular}{|l} 
Namin S \\
Dump truck-T8842F
\end{tabular} & $\begin{array}{l}\text { Pool- TPS Sadang Golf- TPS Puri KIIC- } \\
\text { TPS Hotel Delonix-TPS RS. Islam-TPS } \\
\text { Fyover-PoolTPA-Pool }\end{array}$ & $\begin{array}{l}\text { Pool-TPS RS. IIslm-TPS Fyover-TPS Puri KIIC- } \\
\text { TPS Sadang Golf-TPS Hotel Delonix-TPA.Pool }\end{array}$ \\
\hline 7 & $\begin{array}{l}\text { Abas } \\
\text { Oump truck-Eg263WQ }\end{array}$ & 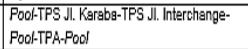 & $\begin{array}{l}\text { Pool-TPS JI. Interchange-TPS JI. Karabs-TPS } \\
\text { Interngsional Karavirng Barat-TPA-Pool }\end{array}$ \\
\hline 8 & $\begin{array}{l}\text { Pamin S } \\
\text { Dump truck-Eg335xX }\end{array}$ & $\begin{array}{l}\text { Pool-TPS Perempotan Passe Cidombas } \\
\text { (Telukjambe).TPS Puri Pinayungan-Pool- } \\
\text { TPA-Fool }\end{array}$ & $\begin{array}{l}\text { Pool.TPS Perempstan passar Cidombs-TPS Puri } \\
\text { Pinayungan-TPA-Fool }\end{array}$ \\
\hline 8 & $\begin{array}{l}\text { Surdja W } \\
\text { Dump tnok-T8804F }\end{array}$ & $\begin{array}{l}\text { Pool-TPS BMJJ-TPS PDAM-TPS RMI. } \\
\text { Mangkabsyan-TPS RM. Bu Cuou-TPS JI. } \\
\text { Syech Quro - TPS JI. Rawagabus-TPS } \\
\text { Perumghan Joher Indeh Pool-TPA-Pool } \\
\end{array}$ & $\begin{array}{l}\text { Pook-TPS BMJ-TPS PDAM-TPS J. SyechQuro- } \\
\text { TPS Perum Johar Indah-TPS JI. Rawabsgus-TPS } \\
\text { RM. Mangksbayan-TPS RM. Bu Cuuu-TPA-Pool }\end{array}$ \\
\hline 10 & & $\begin{array}{l}\text { Pool-TPS Perumghan Perumnss-TPS } \\
\text { Kampung Budays-TPS Depan Rumsh Sakit }\end{array}$ & $\begin{array}{l}\text { Pool-TPS Depgn RS. Mitra-TPS Kampung } \\
\text { Budgya-TPS Perumghan Perumnas Adiarsa- }\end{array}$ \\
\hline 18 & 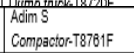 & $\begin{array}{l}\text { Pool-TPS JI. Gempol-TPS Tanjing Mekgr- } \\
\text { TPS Fly Over.Pool-TPA-Pool }\end{array}$ & $\begin{array}{l}\text { Pool.TPS Flyover.TPS Taniung Mekgr.TPS } \\
\text { Gempol 2-TPS Gempol 1-TPA-POool }\end{array}$ \\
\hline & & $\begin{array}{l}\text { Pool/FPS Punwadeng (Gempol)-Pool-TPA. } \\
\text { Pool (ntassi 1) }\end{array}$ & Pool-TPS Punwadang-Gempol (ritas i 1)-TPA.Pool \\
\hline 20 & Compastor-T8762F & $\begin{array}{l}\text { Pool-TPS RS. Mandgya-TPS Ulekan-Pool- } \\
\text { TPA Jalugang-Pool (nitgsi 2) }\end{array}$ & $\begin{array}{l}\text { Pool-TPS RS. Mandayg-TPS Ulekan-TPA.Pool } \\
\text { (ntasi 2) }\end{array}$ \\
\hline 21 & \begin{tabular}{|l|} 
Eman Aki \\
Amm Roll-T8786F F
\end{tabular} & $\begin{array}{l}\text { Pool-Passr Kossmbi-PT. GLDN-Water Park- } \\
\text { Pool-TPA-Pool }\end{array}$ & $\begin{array}{l}\text { Pool-FPS PT. GLDN-TPS Pasar Kosambi-TPS } \\
\text { Water Park-TPA-Pool }\end{array}$ \\
\hline 22 & \begin{tabular}{|l|} 
Sarinudin \\
Am Roll-T8861F
\end{tabular} & $\begin{array}{l}\text { Pool-TPS Resinds-TPS Busna Asni-TPS } \\
\text { Kosasmbi-Pool-TPA.Pool } \\
\end{array}$ & $\begin{array}{l}\text { Pool-TPS Resinds-TPS Busng Asi-TPS } \\
\text { Kosambi-TPA-Pool }\end{array}$ \\
\hline 23 & $\begin{array}{l}\text { Herv Susanto } \\
\text { Amm Roll-T8858F }\end{array}$ & $\begin{array}{l}\text { Pool-TPS Tegel Luhur-TPS KIIC (TPS } \\
\text { Dansu)-TPS Lotus Lake Golf (Bgdami). } \\
\text { TPS Sindang Reret-Pool-TPA-Pool }\end{array}$ & \begin{tabular}{|l} 
Pool-TPS Tegal Luhur-Sinding Reret-TPS KIC \\
(Donau)-TPS Lotus Lake Golf-TPA-Pool
\end{tabular} \\
\hline 24 & \begin{tabular}{|l|} 
Wawan \\
Am RollT8233F
\end{tabular} & $\begin{array}{l}\text { Pool.TPS J. Johrer-TPS KW4-TPS KWB- } \\
\text { Pool-TPA.PPool }\end{array}$ & $\begin{array}{l}\text { Pool-TPS JI. Johar KW 4-TPS JI. Johar KW Q- } \\
\text { TPA-Pool }\end{array}$ \\
\hline 25 & $\begin{array}{l}\text { Ksni } \\
\text { Am Roll-T8788F }\end{array}$ & Pool-TPS KWE-TPS RSUD-Pool-TPA-Pool & Pool.TPS JI. Johar KW B-TPS RSUD-TPA-Pool \\
\hline 28 & $\begin{array}{l}\text { Karyani } \\
\text { Amm Roll-T8871F }\end{array}$ & 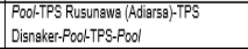 & $\begin{array}{l}\text { Pool-TPS Rusunawa (Adiarsg)-TPS Disnaker- } \\
\text { TPA-Pool }\end{array}$ \\
\hline 27 & $\begin{array}{l}\text { M. Solehman } \\
\text { Amm Roll-T8273F }\end{array}$ & $\begin{array}{l}\text { Pool-Pundong-SMPN } 2 \text { Kargwang Timur- } \\
\text { Sepanjigng Palumbonssar Pool-TPA-Pool }\end{array}$ & $\begin{array}{l}\text { Pool-TPS SMPN } 2 \text { Karawanng Timur.TPS } \\
\text { Palumbonssir-TPS Pundong-TPA-Pool }\end{array}$ \\
\hline 28 & $\begin{array}{l}\text { Ysygn } \\
\text { Amm Rollt-T8853F }\end{array}$ & $\begin{array}{l}\text { Pool-TPS Palawad-TPS Johrr-Pool-TPA. } \\
\text { Pool }\end{array}$ & Pool-TPS Palawsod-TPS Johrs-TPA.Pool \\
\hline 28 & \begin{tabular}{|l|} 
Dadgn $\$$ \\
Am Roll-T8003F
\end{tabular} & 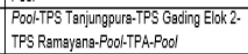 & $\begin{array}{l}\text { Pool-TPS Taniungpura-TPS Gading Elok 2.TPS } \\
\text { Regmygng-TPA-Pool }\end{array}$ \\
\hline 30 & \begin{tabular}{|l} 
Kgij B Kampil \\
Dump Truk-T81400
\end{tabular} & $\begin{array}{l}\text { Pool-TPS Rummh Sakit Joko Pramono-TPS } \\
\text { Moksen-TPS Jatirasa-Jl. Insur Akk-Pool- } \\
\text { TPA-Pool } \\
\end{array}$ & $\begin{array}{l}\text { Pool-TPS Jafirasg-TPS RS. Joko Pranomo-TPS } \\
\text { Jl. Unsur Aki-TPS Moksen-TPA-Pool }\end{array}$ \\
\hline 31 & $\begin{array}{l}\text { Karyono } \\
\text { Dump Truck-T8333F }\end{array}$ & $\begin{array}{l}\text { Pool.FPS Resinds-TPS Alsm Sori-Pool- } \\
\text { TPA.Pool }\end{array}$ & Pool-TPS Resinds-TPS Alam Sgri-TPA-Pool \\
\hline 32 & \begin{tabular}{|l|l|} 
M. Solehmmgn \\
Dump Trukk-T8273F
\end{tabular} & $\begin{array}{l}\text { Pool-TPS Johgr, TPS Tupgrev-TPS } \\
\text { Kentrbumi-Pool-TPA-Pool } \\
\end{array}$ & $\begin{array}{l}\text { Pool-TPS Johsr-TPS Tupgrev-TPS Kertabumi- } \\
\text { TPA-Pool }\end{array}$ \\
\hline 33 & $\begin{array}{l}\text { Ujun Jungedi } \\
\text { Comosctor-T8763F }\end{array}$ & Pool-TPS Tupgrev-Pool-TPA-Pool & Pool.TPS Tuparev-TPA.Pool \\
\hline 34 & $\begin{array}{l}\text { Endang Sulseman } \\
\text { Amm Roll-T8788FF }\end{array}$ & $\begin{array}{l}\text { Pool-TPS Pasar Kondang Kari.TPS SMIKN } \\
\text { 3-TPS Pemda 2-Pool-TPA.Pool }\end{array}$ & $\begin{array}{l}\text { Pool-TPS Peemds-TPS Passa Kondang-TPS } \\
\text { SMKN } 3 \text { Karswang-TPA-Pool }\end{array}$ \\
\hline 35 & \begin{tabular}{|l|} 
Uming \\
Am Roll-T8781F
\end{tabular} & $\begin{array}{l}\text { Pool-TPS Pasar Johar-TPS Klani-Pool-TPA. } \\
\text { Pool }\end{array}$ & Pool-TPS Johrr-TPS Klari-TPA-Pool \\
\hline 36 & $\begin{array}{l}\text { Novi Subgndgr } \\
\text { Am Rollt }-8815 \mathrm{~F}\end{array}$ & Pool-TPS Fyover-Pool-TPA-Pool & Pool-TPS Flyover-TPA.Pool \\
\hline 37 & \begin{tabular}{|l|} 
Loo Suwardi \\
Am RollT T8751F
\end{tabular} & $\begin{array}{l}\text { Pool.TPS JI. Johar Permgi-TPS Flyover- } \\
\text { Pool-TPA.Pool }\end{array}$ & $\begin{array}{l}\text { Pool-TPS Flyover-TPS JI. Johar Permsi-TPA- } \\
\text { Pool }\end{array}$ \\
\hline 38 & $\begin{array}{l}\text { Rasdi } \\
\text { Amm Roll-T8751F }\end{array}$ & $\begin{array}{l}\text { Pool/TPS Perumnas blok S.TPS Pasgr } \\
\text { Wadas Perumngs-TPS Blok DPO-Pool- } \\
\text { TPA-Pool }\end{array}$ & \begin{tabular}{|l} 
Pool.TPS blok DPO-TPS Passar Wadas \\
Perumnas-TPS Perumnas blok S.TPA.Pool
\end{tabular} \\
\hline
\end{tabular}

Hasil dan jarak rute alternatif pengangkutan sampah ini kemudian dibandingkan dengan jarak rute pengangkutan sampah eksisting saat ini sehingga dapat diketahui bahwa rute alternatif yang diperoleh dari Networt Analyst pada Sistem Informasi Geografis (SIG) tersebut lebih efektif atau tidak yang dapat dilihat pada Tabel 8.

Tabel 8. Perbandingan jarak tempuh rute alternatif dan rute eksisting
E-ISSN: 2714-8025

\begin{tabular}{|c|c|c|c|c|}
\hline No & Kendaaran & $\begin{array}{c}\text { Jarak Rute } \\
\text { Alternatif } \\
(\mathrm{km})\end{array}$ & $\begin{array}{c}\text { Jarak Rute } \\
\text { Eksisting } \\
(\mathrm{km})\end{array}$ & $\begin{array}{c}\text { Selisih } \\
\text { Jarak } \\
(\mathrm{km})\end{array}$ \\
\hline 1 & Tarmin Miharja & 56,11 & 88,43 & 32,32 \\
\hline 2 & Aji Sarmaji & 54,45 & 81,22 & 26,77 \\
\hline 3 & Onem S & 52,61 & 81,5 & 28,89 \\
\hline 4 & Andri & 55,07 & 82,19 & 27,12 \\
\hline 5 & Didi & 67,08 & 111,73 & 44,65 \\
\hline 6 & Namin S & 66,54 & 104,31 & 37,77 \\
\hline 7 & Abas & 60,81 & 92,96 & 32,15 \\
\hline 8 & Parmin S & 55,61 & 90,53 & 34,92 \\
\hline 9 & Surdja W & 68,63 & 107,42 & 38,79 \\
\hline 10 & Deni P & 62,07 & 96,64 & 34,57 \\
\hline 11 & Agus Jajuli & 55,41 & 88,89 & 33,48 \\
\hline 12 & Sanawi & 65,69 & 100,86 & 35,17 \\
\hline 13 & Jajang & 56,91 & 96,25 & 39,34 \\
\hline 14 & Kanim Ardo & 61,90 & 93,32 & 31,42 \\
\hline 15 & Edi Kurnia & 52,58 & 82,32 & 29,74 \\
\hline 16 & Priyono & 59,07 & 97,63 & 38,56 \\
\hline 17 & Aep Sujana & 57,13 & 83,83 & 26,7 \\
\hline 18 & Ajid & 65,56 & 104,76 & 39,2 \\
\hline 19 & Adim S & 61,6 & 86,52 & 24,92 \\
\hline \multirow{2}{*}{20} & \multirow{2}{*}{ Dedi Karnadi } & 52,75 & 100,74 & 47,99 \\
\hline & & 60,37 & 92,86 & 32,49 \\
\hline 21 & Eman Aki & 58,77 & 78,57 & 19,8 \\
\hline 22 & Saripudin & 60,5 & 112,85 & 52,35 \\
\hline 23 & Heru Susanto & 76,42 & 105,17 & 28,75 \\
\hline 24 & Wawan & 53,87 & 79,54 & 25,67 \\
\hline 25 & Karji & 59,36 & 84,68 & 25,32 \\
\hline 26 & Karyani & 56,99 & 93,75 & 36,76 \\
\hline 27 & M. Solehman & 54,81 & 84,48 & 29,67 \\
\hline 28 & Yayan & 59,02 & 89,24 & 30,22 \\
\hline 29 & Dadan S & 54,19 & 88,33 & 34,14 \\
\hline 30 & Kaji B Kampil & 54,86 & 82,41 & 27,55 \\
\hline 31 & Karyono & 57,69 & 82,13 & 24,44 \\
\hline 32 & M. Solehman & 58,68 & 84,96 & 26,28 \\
\hline 33 & Ujun Junaedi & 53,67 & 75,54 & 21,87 \\
\hline 34 & Endang Sulaeman & 53,91 & 96,69 & 42,78 \\
\hline 35 & Uming & 52,5 & 90,82 & 38,32 \\
\hline 36 & Novi Subandar & 54,34 & 79,2 & 24,86 \\
\hline 37 & Ido Suwardi & 55,73 & 84,96 & 29,23 \\
\hline 38 & Rasdi & 60,97 & 93,89 & 32,93 \\
\hline & Total & 2103,67 & 3552,12 & 1267,9 \\
\hline
\end{tabular}

Terdapat perbandingan yang cukup besar jarak tempuh sebelum analisis NA antara rute eksisting sebelum dan sesudah dilakukan analisis pada 5 kecamatan di Kabupaten Karawang. Hal ini disebabkan karena pemilihan urutan TPS-TPS sebagian rute eksisting tidak memilih tujuan pertama TPS dengan titik yang paling dekat dengan pool kendaraan yang menyebabkan pengulangan jalan pada rute eksisting.

Hasil running dari Network Analyst untuk sistem pengangkutan sampah pada salah satu pengangkutan sampah menggunakan pola SCS menghasilkan jarak rute alternatif yang lebih pendek dari rute sebelumnya. Rute pertama sebelum dilakukan analisis NA jarak rute eksisting sebesar 107,42 km dan setelah dilakukan analisis jarak tersebut mengurangi pengurangan yaitu $68,63 \mathrm{~km}$. Dari kedua pengangkutan tersebut mempunyai selisih sebesar $38,79 \mathrm{~km}$ dikarenakan pengambilan urutan TPS tidak memilih dekat dengan titik pool kendaraan yang menyebabkan jarak pengambilan menjadi lebih jauh.

Berikut adalah hasil perhitungan jumlah trip/hari kendaraan pengangkutan sampah pada 5 kecamatan yaitu Karawang Barat, Karawang Timur, Telukjambe Barat, Telukjambe Timur dan Klari: 
Kendaraan pengangkutan sampah ke-1 yaitu armada pengangkutan sampah jenis kendaraan dump truck, yang melayani empat (4) TPS yaitu TPS RS. Bayukarta, Jl. Niaga, TPS Anjun, dan TPS Jl. Kertabumi. Rute yang diakses dapat dilihat pada Tabel 9.

Tabel 9. Jarak dan waktu

\begin{tabular}{|c|c|c|c|}
\hline Kendaraan & TPS & \begin{tabular}{|c|} 
Jarak \\
tempuh tiap \\
TPS (jam)
\end{tabular} & $\begin{array}{c}\text { Waktu } \\
\text { di lokasi } \\
\text { (jam) }\end{array}$ \\
\hline \multirow{5}{*}{$\begin{array}{l}\text { T8801F } \\
\text { Dump } \\
\text { truck }\end{array}$} & Bayukarta & 0,08 jam & $0,45 \mathrm{jam}$ \\
\hline & \begin{tabular}{|l} 
Jl. Niaga \\
\end{tabular} & $0,52 \mathrm{jam}$ & $0,88 \mathrm{jam}$ \\
\hline & Anjun & 0,038 jam & $0,35 \mathrm{jam}$ \\
\hline & \multirow{2}{*}{$\begin{array}{l}\text { JI. Kertabumi } \\
\text { Total }\end{array}$} & 0,02 jam & $0,21 \mathrm{jam}$ \\
\hline & & \multicolumn{2}{|c|}{2,556 jam } \\
\hline
\end{tabular}
tempuh pengangkutan sampah

Tabel 10. Waktu tempuh pengambilan dan pengangkutan sampah

\begin{tabular}{|c|c|c|c|c|c|c|}
\hline $\begin{array}{c}\text { Nd } \\
\text { (rit/hari) }\end{array}$ & $\begin{array}{c}\text { Waktu } \\
\text { kerja per } \\
\text { hari (H) }\end{array}$ & $\begin{array}{c}\text { Waktu dari } \\
\text { pool ke TPS } \\
\text { pertama (t1) }\end{array}$ & $\begin{array}{c}\text { Waktu dari } \\
\text { TPA menuju } \\
\text { ke pool (t2) }\end{array}$ & $\begin{array}{c}\text { Waktu rata-rata } \\
\text { pembongkaran } \\
\text { di TPA (S) }\end{array}$ & $\begin{array}{c}\text { Waktu } \\
\text { tempuh } \\
\text { rata- rata } \\
\text { TPS - TPA } \\
(\mathrm{x})\end{array}$ & $\begin{array}{c}\text { Faktor } \\
\text { of } \\
\text { route } \\
(\mathrm{W})\end{array}$ \\
\hline 1 & $6 \mathrm{jam}$ & $0,08 \mathrm{jam}$ & 1,04 jam & $0,225 \mathrm{jam}$ & $1,20 \mathrm{jam}$ & 0,15 \\
\hline
\end{tabular}

Perhitungan jumlah trip kendaraan pengangkutan sampah:

$$
\begin{aligned}
& \text { TSCS }=\text { PSCS }+\mathrm{x}+\mathrm{S} \\
& \quad=2,556+1,20+0,225=3,981 \text { jam } \\
& \\
& \begin{aligned}
\mathrm{Nd} & =\{\mathrm{H}(1-\mathrm{W})-(\mathrm{t} 2+\mathrm{t} 1)\} / \mathrm{TSCS} \\
& =\{6(1-0,15)-(1,04+0,08)\} / 3,981 \\
& =0,99 \text { trip/hari atau } 1 \text { trip/hari }
\end{aligned} \\
& \text { Jadi kemampuan kendaraan } \\
& \text { pengangkutan sampah dari pool menuju } \\
& \text { TPS ke TPS lainnya dan menuju TPA } \\
& \text { kemudian kembali lagi ke pool mampu } \\
& \text { melakukan rotasi sebanyak } 1 \text { trip/hari. }
\end{aligned}
$$

Tabel 11. Jumlah biaya bahan bakar yang dibutuhkan pada kendaraan pengangkut

\begin{tabular}{|c|c|c|}
\hline Rute & $\begin{array}{c}\text { Jarak total rute } \\
\text { pengangkutan }(\mathrm{km})\end{array}$ & $\begin{array}{c}\text { Waktu } \\
\text { operasional } \\
\text { (jam) }\end{array}$ \\
\hline $0-1-2-3-4-\mathrm{X}-0$ & $56,11 \mathrm{~km}$ & 2,24 jam \\
\hline \multicolumn{2}{|c|}{ Biaya bahan bakar } & Rp. $65.227,-$ \\
\hline
\end{tabular}

Keterangan : 0. Pool Kendaraan; 1. RS. Bayukarta; 2. JI. Niaga ; 3. TPS Anjun; 4. JI. Kertabumi; X. TPA; 0. Pool Kendaraan
Kendaraan pengangkutan sampah ke-2 jenis kendaraan dump truck, yang, melayani 1 (satu) TPS yaitu TPS Pasar Baru Karawang. Rute yang diakses dapat dilihat pada Tabel 12

Perhitungan jumlah trip kendaraan pengangkutan sampah:

$$
\begin{aligned}
\text { Phcs } & =p c+u c+d b c \\
& =(0,15+0,04+0,04) \\
& =0.23 \text { jam/trip } \\
\text { Thcs } & =\mathrm{P} \text { hcs }+\mathrm{h}+\mathrm{s} \\
& =0,23+1,20+0,04 \\
& =1,47 \text { jam/trip } \\
\text { Nd } & =\{\mathrm{H}(1-\mathrm{W})-(\mathrm{t} 2+\mathrm{t} 1)\} / \text { Thcs } \\
& =\{6(1-0,15)(1,04+0,15)\} / 1,47 \\
& =2,65 \text { trip/hari atau } 3 \text { trip/hari }
\end{aligned}
$$

Jadi kemampuan pengangkutan sampah menggunakan kendaraan dump truck dalam 1 hari mampu melakukan ritasi sebanyak 3 trip/hari. 
Tabel 12. Jarak dan waktu tempuh pengangkutan sampah

\begin{tabular}{|c|c|c|c|c|c|c|c|c|}
\hline $\begin{array}{c}\text { Waktu } \\
\text { kerja } \\
\text { per } \\
\text { hari } \\
(\mathrm{H})\end{array}$ & $\begin{array}{l}\text { Waktu } \\
\text { dari pool } \\
\text { ke TPS } \\
\text { pertama } \\
(\mathrm{t} 1)\end{array}$ & $\begin{array}{l}\text { Waktu } \\
\text { dari TPA } \\
\text { menuju } \\
\text { ke pool } \\
\text { (t2) }\end{array}$ & $\begin{array}{l}\text { Waktu } \\
\text { rata -rata } \\
\text { pembong } \\
\text { karan di } \\
\text { TPA (S) }\end{array}$ & $\begin{array}{l}\text { Waktu } \\
\text { tempuh } \\
\text { rata-rat } \\
\text { a TPS - } \\
\text { TPA (h) }\end{array}$ & $\begin{array}{c}\text { Waktu } \\
\text { mengambi } \\
\text { I kontainer } \\
\text { (pc) }\end{array}$ & $\begin{array}{c}\text { Waktu } \\
\text { meletak } \\
\text { kan } \\
\text { kontaine } \\
r \\
r(u c) \\
\end{array}$ & $\begin{array}{l}\text { Waktu } \\
\text { antar } \\
\text { kontaine } \\
\text { r (dbc) }\end{array}$ & $\begin{array}{l}\text { Fakto } \\
\text { rof } \\
\text { route } \\
\text { (W) }\end{array}$ \\
\hline 6 jam & 0,15 jam & 1,04 jam & 0,04 jam & 1,20 jam & 0,15 jam & 0,04 jam & 0,04 jam & 0,15 \\
\hline
\end{tabular}

$$
=128 \text { unit truk pengangkutan }
$$

Tabel 13. Jumlah biaya bahan bakar Yang dibutuhkan pada kendaraan pengangkut

\begin{tabular}{|c|c|c|}
\hline Rute & $\begin{array}{c}\text { Jarak total rute } \\
\text { pengangkutan }(\mathrm{km})\end{array}$ & $\begin{array}{c}\text { Waktu } \\
\text { operasional } \\
\text { (jam) }\end{array}$ \\
\hline $0-1-\mathrm{X}-0$ & $54,45 \mathrm{~km}$ & 2,17 jam \\
\hline \multicolumn{2}{|c|}{ Biaya bahan bakar } & Rp. 63.298,- \\
\hline
\end{tabular}

Keterangan: 0 Pool Kendaraan; 1.

Pasar Baru Karawang; X. TPA; 0 Pool Kendaraan.

Jumlah trip/hari rata-rata yang dihasilkan pada pada kendaraan pengangkutan sampah dengan pola SCS 1 sampai 3 dan untuk pola HCS 2 sampai 3 trip/hari. Perhitungan jumlah truk yang dibutuhkan adalah sebagai berikut:

1. Menentukan jumlah trip/hari

Jumlah trip/hari

= Timbulan sampah yang dihasilkan

$$
\begin{aligned}
& =1.532,234 \mathrm{~m}^{3} / \text { hari } / 6 \mathrm{~m}^{3} \\
& =255 \text { trip } / \text { hari }
\end{aligned}
$$

2. Kebutuhan truk untuk melakukan 255 trip/hari dapat dicari dengan cara sebagai berikut:

a. Kebutuhan truk untuk melakukan 255 trip/hari dapat dicari dengan cara sebagai berikut:

$=$ Jumlah trip/hari $\mathrm{x}$ waktu 1 kali trip

$=255$ trip/hari $\times 3$ jam

\{didapatkan dari 1 hari waktu kerja (6 jam/2)

$=765 \mathrm{jam}$

b. Menentukan jumlah truk yang dibutuhkan

$=$ (Waktu operasi/waktu kerja sehari) $\times 1$ truk pengangkutan

$=(765$ jam $/ 6$ jam $) \times 1$ unit truk pengangkutan
Jadi dari hasil kebutuhan kendaraan pengangkutan sampah pada 5 Kecamatan di Kabupaten Karawang didapatkan kebutuhan kendaraan sebanyak 128 unit kendaraan.

Biaya operasional pengangkutan sampah sebagian besar digunakan untuk membeli bahan bakar kendaraan pengangkutan sampah pada 5 Kecamatan dapat dilihat pada Tabel 14.

Tabel 14. Biaya konsumsi bahan bakar kendaraan pengangkutan sampah 


\begin{tabular}{|c|c|c|c|c|c|}
\hline \multirow{2}{*}{ No } & \multirow{2}{*}{ Kendaraan } & \multicolumn{2}{|c|}{ Jarak Tempuh (km) } & \multicolumn{2}{|c|}{ Biaya (Rp/han) } \\
\hline & & Eksisting & Alternatf & Eksisting & Alternatif \\
\hline 1 & Tarmin Miharia & 88,43 & 56,11 & 102.798 & 85.227 \\
\hline 2 & Ai Samaii & 81,22 & 54,45 & 94.418 & 83.298 \\
\hline 3 & Onems & 81,5 & 52,61 & 94.474 & 81.158 \\
\hline 4 & Andri & 82,18 & 55,07 & 85.545 & 84.018 \\
\hline 5 & Didi & 111,73 & 87,08 & 129.888 & 77.980 \\
\hline 6 & Namin S & 104,31 & 68,54 & 121.260 & 76.190 \\
\hline 7 & Abas & 82,86 & 60,81 & 108.086 & 70.681 \\
\hline 8 & Pamin S & 80,53 & 55,61 & 105.241 & 84.646 \\
\hline$\theta$ & SurdjaW & 107,42 & 88,63 & 124.879 & 79.782 \\
\hline 10 & DeniP & 86,64 & 62,07 & 112.344 & 72.156 \\
\hline 11 & Agus Jajuli & 88,89 & 55,41 & 103.334 & 64.414 \\
\hline 12 & Sanawi & 100,86 & 85,68 & 117.248 & 76.701 \\
\hline 13 & Jajang & 96,25 & 56,81 & 118.890 & 86.157 \\
\hline 14 & Kanim Ardo & 83,32 & 81,80 & 108.484 & 71.958 \\
\hline 15 & Edi Kumia & 82,32 & 52,58 & 85.697 & 81.124 \\
\hline 18 & Priyono & 87,63 & 59,07 & 113.484 & 88.668 \\
\hline 17 & Aep Sujana & 83,83 & 57,13 & 97.452 & 86.413 \\
\hline 18 & Aid & 104,76 & 65,56 & 121.783 & 76.213 \\
\hline 18 & Adim S & 86,52 & 61,6 & 100.579 & 71.678 \\
\hline \multirow{2}{*}{20} & \multirow{2}{*}{ Dedi Kamadi } & 100,74 & 52,75 & 117.110 & 81.321 \\
\hline & & 92,86 & 60,37 & 107.948 & 71.678 \\
\hline 21 & Eman Aki & 78,57 & 58,77 & 81.337 & 88.320 \\
\hline 22 & Saripudin & 112,85 & 60,5 & 131.188 & 70.331 \\
\hline 23 & Heru Susanto & 105,17 & 76,42 & 122.260 & 58.636 \\
\hline 24 & Wawan & 79,54 & 53,87 & 92.465 & 82.623 \\
\hline 25 & Karii & 84,68 & 59,36 & 98.440 & 87.843 \\
\hline 26 & Karyani & 83,75 & 56,88 & 108.984 & 86.250 \\
\hline 27 & M. Solehman & 84,48 & 54,81 & 98.208 & 87.204 \\
\hline 28 & Yayan & 89,24 & 59,02 & 103.741 & 88.610 \\
\hline 28 & Dadan S & 88,33 & 54,18 & 102.683 & 82.995 \\
\hline 30 & Kaii B Kampil & 82,41 & 54,86 & 85.801 & 83.774 \\
\hline 31 & Karyono & 82,13 & 57,68 & 85.476 & 87.134 \\
\hline 32 & M. Solehman & 84,86 & 58,68 & 98.766 & 88.215 \\
\hline 33 & Ujun Junaedi & 75,54 & 53,67 & 87.815 & 82.391 \\
\hline 34 & Endang Sulaeman & 96,69 & 53,81 & 112.402 & 88.215 \\
\hline 35 & Uming & 80,82 & 52,5 & 105.578 & 81.031 \\
\hline 38 & Novi Subandar & 79,2 & 54,34 & 92.070 & 83.170 \\
\hline 37 & Ido Suwardi & 84,88 & 55,73 & 98.768 & 84.786 \\
\hline 38 & Rasdi & 83,89 & 60,87 & 109.147 & 70.877 \\
\hline & Total & 3552,12 & 2103,67 & 4.133 .735 & 2.633 .879 \\
\hline
\end{tabular}

Biaya konsumsi bahan bakar pada rute eksisting adalah sebesar Rp. 4.133.735 per hari lebih besar dari biaya konsumsi bahan bakar pada rute alternatif yang sudah dianalisis yaitu sebesar Rp. 2.633.879 per hari. Berdasarkan perbandingan biaya konsumsi bahan bakar pada rute eksisting dan biaya konsumsi bahan bakar pada rute setelah optimasi terjadi pengurangan sebesar Rp. 1.479.856 per hari. Perbandingan ini menunjukkan bahwa dengan optimasi jarak pada rute pengangkutan juga berdampak pada penghematan biaya operasional pengangkutan sampah.

\section{KESIMPULAN}

Berdasarkan penelitian yang dilakukan pada 5 kecamatan di Kabupaten Karawang jumlah TPS yang dilayani oleh Dinas Lingkungan Hidup dan Kebersihan Kabupaten Karawang sebanyak 111 TPS yaitu Kecamatan Karawang Barat 37 TPS, Karawang Timur 35 TPS, Telukjambe Barat 2, Telukjambe Timur 34 TPS dan Klari 3 TPS.

Jalur eksisting kendaraan pengangkutan sampah pada 5 Kecamatan memiliki 38 kendaraan. Pengambilan dan pengangkutan sampah di TPS pertama tidak dekat dengan titik pool kendaraan dan TPS terakhir yang dilayani tidak dijadikan jalur terakhir pengambilan sebelum menuju ke TPA. Kendaraan pengangkutan sampah kembali ke pool setelah dari TPS terakhir, kemudian dilakukan pergantian supir, selanjutnya menuju ke TPA pada pukul 01.00 WIB.

Berdasarkan hasil analisis menggunakan Network Analyst hasil jarak rata-rata $53,94 \mathrm{~km}$ dan waktu tempuh 2,32 jam mempunyai selisih jarak dengan rute eksisting $32,51 \mathrm{~km}$ dan waktu tempuh 1,31 jam pada 38 kendaraan pengangkutan sampah. Jalur pengangkutan sampah menjadi lebih efektif karena memiliki jarak dan waktu tempuh lebih cepat dari rute eksisting. Jumlah trip/hari rata rata pada kendaraan pengangkutan sampah untuk sistem pengangkutan dengan pola SCS rata-rata 1 sampai 3 trip/hari dan untuk pola HCS 2 sampai 3 trip/hari.

Estimasi timbulan sampah yang dihasilkan 5 Kecamatan di Kabupaten Karawang sebanyak 1.532,234 m3 /hari. Hasil perhitungan estimasi timbulan sampah jumlah kendaraan yang dibutuhkan sebanyak 128 unit kendaraan. Biaya konsumsi bahan bakar kendaraan pada rute eksisting sebesar Rp. 4.133.735 per hari sedangkan sesudah dilakukan analisis menjadi Rp. 2.633.879 per hari, jadi penurunan sebanyak Rp. 1.479 .856 per hari berarti bisa menghemat biaya operasional pengangkutan sampah.

\section{DAFTAR PUSTAKA}

Angrealiany, N. 2014, Perhitungan Jumlah Trip Kendaraan Pengangkut Sampah (Optimasi Kendaraan Pengangkut), Politeknik Negeri Pontianak.

Arinal Haq, F, Imran, A, dan Fitria, L, 2013, $\begin{array}{llr}\text { Penentuan } & \text { Rute } & \text { Kendaraan } \\ \text { Pengangkutan } & \text { Sampah } & \text { dengan } \\ \text { Menggunakan } & \text { Metode } & \text { Nearest }\end{array}$ Neighbour Studi Kasus PD Kebersihan Kota Bandung. Vol 1 No: 1, 22-32, Institut Teknologi Nasional. 
ISSN: 1979-8415

E-ISSN: 2714-8025

Badan Pusat Statistik, 2019, Kabupaten Karawang Dalam Angka 2019, Kabupaten Karawang.

Dinas Lingkungan Hidup dan Kehutanan, 2018, Kabupaten Karawang.

Ofyar, Z.T, 2000, Perencanaan dan Pemodelan Transportasi, ITB, Bandung.

Pramartha, I,K,T,S, 2013, Analisis Pengelolaan Pengangkutan Sampah di Kecamatan Klungkung Kabupaten Klungkung, Universitas Udayana, Denpasar.

Ristandi, E, 2004, Sistem Informasi Penelusuran Jalur Jalan Tercepat untuk Kunjungan Wisata Kota, Bandung Utara.

Standar Nasional Indonesia, 1995, Nomor 19-3983, Tentang Pengelolaan Sampah di Pemukiman.

Sustanugraha, D, 2013, Aplikasi Sistem Informasi Geografis (SIG) Untuk
Penentuan Lokasi Tempat Pembuangan Akhir (TPA) Sampah di Wilayah Kota Yogyakarta, Kabupaten Sleman, dan Kabupaten Bantul (Kartamantul), Skripsi, Jurusan Pendidikan Geografi UNY, Yogyakarta.

\section{BIODATA PENULIS}

Dra. Yuli Pratiwi, M.Si., lahir di Purwokerto pada tanggal 27 Juli 1964 menyelesaikan pendidikan S1 bidang ilmu Biologi Lingkungan dari Universitas Gadjah Mada tahun 1989, S2 bidang Ilmu Lingkungan dari Universitas Gadjah Mada tahun 2004. Saat ini tercatat sebagai Dosen Tetap di Jurusan Teknik Lingkungan dengan jabatan akademik Lektor Kepala pada bidang minat Pengelolaan Persampahan 